\title{
Joint forest management in India: implications and opportunities for women's participation in community resource management
}

\author{
Sophie Maksimowski
}

\author{
This paper was written under the supervision of Professor Sally Humphries, \\ Department of Sociology and Anthropology, College of Social and Applied Human Sciences \\ University of Guelph
}

\begin{abstract}
In recent years, state decentralization of control over community resource management has been increasing on a global scale. This process is largely intended to compensate for bureaucratic inefficiencies through the involvement of local users in state conservation efforts. Since India established its National Forest Policy of 1988, such a shift has occurred in natural resource management from the national to the local level. During the 1990's this process of decentralization was accelerated under India's Joint Forest Management (JFM) Policy. This paper examines the implications of JFM in involving local stakeholders with forest management practices, and specifically, women's role within JFM and the degree of their participation within village forest institutions. Women are the primary collectors of forest products in rural India, and it is recognized that as a forest-dependent group, they ought to be involved in decision-making within these institutions for the sustainability of village livelihoods and conservation efforts. The success of JFM programs in this regard requires that a greater role for women be established through a gender policy within JFM. Both within and outside of state policy, measures to enhance women's participation must take into account social relations and structures that perpetuate women's exclusion, and identify ways through which these structures can be transformed. Ultimately, promoting women's empowerment and livelihood rights and opportunities are essential preconditions to their effective participation.
\end{abstract}

$\mathrm{O}^{\mathrm{s}}$ ver the last couple decades, decentralization of resource management and granting of resource access rights to local communities has become a policy model for numerous developing countries[1a]. In India, the government has been implementing community forestry management programs in villages across the country for over two decades[2a]. India comprises 63.72 million hectares of forest cover, almost all of which is state-owned and controlled, and 40 per cent of which is degraded[3a]. The Government of India has recognized that the mass-scale degradation of India's forests throughout the country and undermining of rural livelihoods can be attributed to past governance failures[2a]. The institutional devolution of user rights from very centralized control towards local management recognizes the limitations of inflated government bureaucracies in assessing and managing resources at the community level. Governance failures are owed to a supposed information gap between local forest conditions faced by daily users and the partial knowledge distant forest departments can gather on these resources. It is assumed that communities can better monitor and enforce rules to protect community resources and thus should have some control over their management[4a]. Joint Forest Management (JFM) is one such program of decentralization which entails the transfer of powers to institutions within local communities, or their creation where these institutions are absent[5a]. Communities often enter into power-sharing arrangements with the state through the enactment of local measures to promote conservation and ideally improve access to resources. In this, it is also assumed that local users will be more capable than state departments in equitably distributing the benefits from managed forests[2a]. However, this conception of participation in community resource management entails an erroneous assumption of rural communities as homogenous groups with equally vested powers and interests[6a].

Women in rural India, as in many developing countries, are the primary collectors of forest products used for household consumption and sale. This gendered division of labour in which women are the primary users of forest resources such as fuel, fodder, medicines, food and marketable non-timber forest products (NTFPs) indicates that they should be involved in the management and protection of community forests. However, the institutional structures of local governance in India have largely limited the participation of women in this environmental governance capacity, and men have assumed the dominant role in decision-making concerning resource management at the local and state levels. Though there do exist communities that have overcome numerous barriers to include women in forest resource management, these cases are generally exceptions to the rule. The standard role of women as primary users and of men, and particularly elite men, as 
forest managers, presents a challenge to the sustainability of Joint Forest Management in India.

It has been argued by numerous theorists that a desire for participation in resource management programs will be based upon the benefits that users gain through such institutions[2]. Under forest management, these benefits include rights to access forest lands and resources which need to be in place if a state-led attempt at conservation and sustainable development is to be successful. However, marginalized groups in rural India face particular barriers to participation through these programs as a result of their social, economic and political disempowerment. Constricted in their ability to effectively participate in forest management, the benefits these groups receive are far more precarious. Poor women are the primary stakeholders in terms of access to community forest resources and their ability to obtain forest resources is in turn affected by management processes from which they are largely excluded[7a]. Women, and particularly the most socioeconomically marginalized and forest-dependent women, need to be involved in this process of decision-making if forest management is to be participatory in practice and not just in rhetoric. Poor women, as the most marginalized of stakeholders to forest products under state forest policies, need to be politically empowered in any participatory process. The success of JFM programs in reversing forest degradation and improving rural livelihoods will require the carving out of a greater role for forest-dependent groups, including women.

\section{FOREST MANAGEMENT UNDER STATE AND COLONIAL CONTROL}

For nearly 100 years under colonial rule, forests in India were managed by the central government to ensure the availability of resources for national purposes, both in the present and in the future. Hardly any concern was granted to local user rights during this time. Rather, forests were seen as needing protection from local people[8a]. India's first National Forest Policy since independence, established in 1952, ushered in a new era of centralized and restrictive management of forests. This policy stipulated that village community use of local forest resources "should in no event be permitted at the cost of national interests"[9a]. For decades, use of local forests by surrounding communities was often greatly restricted in favour of preserving national interests for commercial exploitation, such as the conversion of 'low value' mixed forests into 'high value' plantations[9b][10]. These institutional structures surrounding forest management were inherited from colonial rule, which prioritized state industry, agriculture and development needs over livelihood opportunities for local people. Many researchers have pointed to the negative impact these production-oriented policies had on conservation through neglecting the needs of local communities[10]. The 1972 Indian Wildlife Protection Act led to the enforcement of overly strict rules and assignment of protected areas with an often hostile approach towards local communities, severely limiting local user rights[11a].

Through Social Forestry policy in the 1980s, plantations of eucalyptus and other timber species were planted with limited attention given to the creation of timber plantations and non-timber forest products for local use[12][13a]. Timber has been institutionally defined as the primary forest good through decades of centralized forest management. Contemporarily under JFM, this policy focus is perpetuated through the continued prioritization of timber lots and the sale of lucrative forest products to industries. Non-timber forest products (NTFPs) are a predominant source of livelihood for forest dependent women, but these products continue to be considered under forest policy as "minor" goods[14a]. The legal, policy and marketing environments for NTFP collection and processing in India do not assist local people who are economically dependent upon these products. Rather, they are constrained by government regulations that restrict the sale, processing and transport of these products. Legal ownership rights for tribal groups are contained within measures such as the 1996 PESA Act (Panchayat Extension to Scheduled Areas) and the Forest Dweller's Act of 2006. However, with regards to implementation there is significant variation across states in India, and people who gather these NTFPs often have no right to process or sell them on the open market[15a].

Under colonial and state forest management policies, forest-dependent peoples were alienated from an important source of livelihood as a result of restrictive policies that dispossessed groups from their lands, relinquished traditional rights, and criminalized the poor and landless[10][16]. The forest departments of many Indian states found themselves overwhelmed by a growing yet ineffective bureaucracy that could not protect forest plantations or reserves. Due to the success of some isolated participatory management approaches across the country, there was a shift in forest policy following changing development discourse. Nonmarket oriented and ecological benefits from forests became more recognized in forest policy[9c]. Under the National Forest Policy of 1988, Joint Forest Management (JFM) was officially introduced in several states as a participatory means for conserving and sustainably managing forest resources and releasing some of this burden from state forest departments[17]. It was seen as a means to overcome conflicts between various users over community resource rights, the interests of commercial industries, and conservationist policies that restricted both. A major shift in forest policy occurred away from criminalization of poor forest users and livelihood alienation. It was conceived that because local people depend on forest resources to secure their livelihoods, they will likely be able to contribute towards the protection and conservation of these assets for future use[8a]. This conception of resource use and conservation seems to make sense from a state policy 
perspective. The issue is whether or not the main stakeholders of forest resources, namely women, are actually being involved in the process of community forest management.

\section{FOREST POLICY: JOINT FOREST MANAGEMENT}

Joint Forest Management (JFM) is one component of the Government of India's Natural Resource Management (NRM) programs aimed at rural development, poverty alleviation, greater equity, and women's participation and empowerment[18a]. NRM includes other large-scale programs alongside Joint Forest Management such as Wastelands Development, Watershed Development, and Water Resources Development. The proposed main objective behind these strategies is to secure livelihoods for rural people across India and to involve local people in these processes[19a]. In fact, a major reason for the shift in policy towards participation is due to the widespread protests against state-led forest conservation as a result of forest degradation under commercial forestry and the erosion of local livelihoods[13b]. The 1988 Forest Policy presents an important departure in forest management. It is the first time national forest policy has acknowledged the significance of involving local users in forest management and conservation in co-ordinance with improving community livelihoods[2a]. Joint Forest Management has been defined as the [15b]:

...sharing of products, responsibilities, control, and
decision making authority over forest lands, between
forest departments and local user groups, based on a
formal agreement. The primary purpose of JFM is to
give users a stake in the forest benefits and a role in
planning and management for the sustainable
improvement of forest conditions and productivity. A
second goal is to support an equitable distribution of
forest products.

It was assumed that community participation under JFM would enhance conservation measures and ensure that poorer and disadvantaged groups who are dependent on forests for their livelihoods would not be "worse, and preferably better off'[13c]. The policy was followed up in 1990 with guidelines created by the central government for all state governments to implement joint forest management systems through the transfer of daily forest use and management rights to communities, while maintaining state Forest Department legal control of rights over forests[2a]. This would be done through either pre-existing community forest management institutions or newly created institutions, such as village forest committees (VFCs), Forest Protection Committees (FPCs) and Eco-development Committees. The type of local forest institution varies depending upon the legal status and ecological state of the forests being managed. Under JFM, forest communities are being involved in protecting predominately state-owned, degraded forests in exchange for limited legal user rights and benefits, including a percentage share in the sale of forest products[14b]. Both the responsibilities and benefits of community forestry are to be shared by local users and the state through the forest departments[18a].

According to the 2004 Annual Report of the Ministry of Environment and Forests, 84632 JFM committees have been formed, making JFM one of largest resource management programs in the world[2b]. Over 50 million people in India co-manage roughly 17 million hectares with Forest Departments, accounting for 27 per cent of India's forests[2b]. However, the results of these widespread JFM initiatives in India appear mixed, depending upon the measures employed. Some studies indicate improvements in terms of yields in timber and NTFPs, firewood and fodder, while others have recorded poor conservation outcomes as a result of ineffective control of forest management by communities[2b]. It has also been noted that while JFM is a fairly uniform policy, it has been implemented differently in various states across India, with varying degrees of control and resource rights transferred to communities. For example, in Andhra Pradesh, 100 per cent of the benefits from JFM forests accrue to local communities[2c], while in numerous other states, conflicts have arisen between communities and the state over economic benefits from harvested resources.

It seems that the state's primary goal in effecting JFM policy is not to enhance local participation as it has stated, but to increase the management capacities of state forest departments in the context of multiple and conflicting user demands in access to forest resources[13e]. Numerous barriers exist to prevent the success of JFM programs. Particularly, the exclusion of marginalized groups through the participatory rhetoric of community resource management within JFM policy limits the effectiveness of these programs in meeting the needs of forest-dependent groups and the program's sustainability[7a][18].

\section{COMMUNITY RESOURCE MANAGEMENT: USER GROUPS, COMMUNITIES AND CONSERVATION}

There are numerous factors affecting community resource conditions and the outcomes of policy intended to improve these conditions. Agrawal and Chhatre (2006) have classified these as biophysical, social, institutional, demographic, and economic. Most studies of forestry in India have focused upon economic and demographic factors affecting resource condition[20a] and there has not been a very thorough institutional or gender analysis. However, institutional factors have been recognized in the literature on common property resources as central in determining access to forest resources and benefits to various user groups. Under JFM, these variables relate to user representation in management groups, mechanisms for rule making and rule enforcement, and the extent to which local voices are privileged within and beyond the community level[20b]. In 
the past, it was assumed that the existence of poverty and other forms of material deprivation led to ecosystem vulnerability and resource degradation. Resource use was viewed in isolation from the various structures that affect human interactions with the environment. This is evident in the criminalization of poor forest users in rural India under colonial and early state policies. In global development discourse however, there has been a shifting emphasis in addressing basic needs, enhancing local participation, and improving institutional governance. It is within these wider discursive contexts that JFM policy in India has emerged and will continue to evolve.

Political ecology is one perspective through which JFM policy and practice can be examined. This perspective on community resource use and management politicizes the relationships between users and the environment through an analysis of the conditions which shape these interactions. Within this framework, it has been recognized that environmental conditions are mediated through complex human-environment interactions in the context of social, economic, political, historical and cultural factors[21]. The socio-political and economic characteristics of users, not simply the condition of the biophysical environment, directly impact resource management outcomes. This link between human populations and resource degradation is "mediated through institutional form"[20c]. The conditions which structure human interactions with the environment will be reflected in local institutions. Political ecology assumes that local actors are not homogenous individuals and will be unequally affected by changes in the condition of a resource and its management. Such inequalities within communities affect how power will be distributed within local resource institutions. Political ecology assumes that the costs and benefits of resource management will not be shared equally and measures need to be taken to ensure that less powerful groups are not marginalized within the policy process. This framework will be explored through JFM analysis in India, with a particular emphasis on gender and resource management.

Community management is premised on the notion that communities play a key role in local resource management and that this is done through effective local institutions involving various key stakeholders[14b][20d][18b]. While studies on government-initiated community resource management programs do not agree on the results of these programs, most case studies find that structural relationships, such as that between the state and the community, are a key factor in determining outcomes[2b]. Literature on common pool resource management has generally maintained that successful community management necessitates collective action to avoid the issue of free riding, that is, the problem of user over-extraction without maintenance and protection. Resource management requires user investment in terms of time, energy and often money with intended benefits for the entire community[2b]. There are several barriers to collective action however. Theorists have written on the issue of individual self-interest, the supposed 'tragedy of the commons', and the need for formal or informal rule-making institutions to guide the actions of individual users which encourage them to cooperate. Some rules are more conducive towards effective resource management than others. Namely, the nature of rules concerning sharing resource benefits, monitoring costs and the sanctioning of offenders are important determinants of management outcomes[2d]. According to Ostrom (1990), it is important that the costs to participants not be greater than the benefits they would receive from the resources[22]. Similarly, in a study of forest governance in Guatemala, Gibson (2001) found that people are not likely to engage in activities to conserve a given resource unless they accrue livelihood benefits in the process[23].

Community environmental management entails the development of strategies to meet the needs of various groups. Management strategies ultimately determine not only how an environment should be managed, but "whose environment gets managed, by whom and in whose interests"[13f]. An environment, and the natural resources it contains, remains open to interpretation by various actors. User need and dependency on forest resources varies considerably according to the vested interests and powers of different groups, and their ability to secure a livelihood from these resources[14c]. Ecosystems like forests provide an array of products and services that are of commercial, subsistence, cultural, religious and environmental value[24]. Various actors utilize resources for different economic or social purposes, and forests themselves contain an abundant variety of resources that serve a multitude of purposes for both local and non-local groups. These stakeholder groups in turn have different incentives in terms of valuing, using and potentially conserving these resources. Values and attitudes towards forest resources held by members of rural communities are determined by a variety of vested interests, conflicts and trade-offs between various community actors, government departments and local officials[8b]. It is generally theorized that the more dependent a user or group is on a resource, the greater their incentive may be to manage that resource.

Thus it is necessary to view communities as heterogeneous entities composed of members with diversely vested interests. According to many theorists, social categories like "community" are too normative and, as Agrawal and Gibson (1999) have argued, often invented mythical categories that do not reveal much about the realities of human and ecological interaction on the ground. Community can be defined as [15c]:

a set of people (i) with some shared beliefs, including normative beliefs, and preferences, beyond those constituting their collective action problem, (ii) with a more-or-less stable set of members, (iii) who expect to continue interacting with each other for some time to come, and (iv) whose relations are direct (unmediated by third parties) and multiplex. 
This definition aptly describes forest-based communities in India as their members often hold less in common than their dependence on forest resources, and this dependency varies significantly both among and between forest user groups. The rural poor in many parts of India depend to varying extents on forest resources to secure their livelihoods, but other factors such as landlessness generally increase this dependence[20e]. Rather than assuming rural community members are equally dependent on forests, we need to take an informed approach - one based on actual observed actions and practices through the lived experiences of social actors to understand how these dependencies are articulated[24a].

Communities in Southeast Asia and in India in particular are extremely diverse and divided along socioeconomic, class, ethnic, caste and gender lines. These categories such as gender are historically and culturally determined[25a]. Different groups have varying levels of dependency on forests and involvement in their management. Generally speaking, men and women from Scheduled Tribes (STs) are the least involved groups in management of resources which they depend upon highly to secure their livelihoods. In Hindu communities, Scheduled Caste (SC) rural women are fairly dependent on these resources as well, but similarly have a very low level of involvement in their management. It is General Caste (GC) and to some extent Scheduled Caste men who are traditionally in control of local governance and resource management[14a]. In the Terrai region of Nepal, Agrawal and Gupta found that richer, upper caste and more educated households were more likely to participate in resource management groups[1b]. This context of entrenched leadership hierarchies poses serious limitations to participatory resource management under JFM, for the policy assumes that communities are homogenous entities comprised of equal actors with equally vested interests[6a].

Given the diversity of community groups and the propensity of development efforts and institutional policy structures towards elite capture, several authors have questioned the extent to which community forest groups are able to involve women in management processes, and the outcomes of these initiatives in terms of meeting project goals. Many researchers are skeptical that a uniform adoption of JFM across a country as diverse as India will be capable of sustaining collective action by local users. They point to problems of aligning user interests and the tendency for such state programs to overlook the complexities of humanenvironment relationships and community livelihoods[2b]. Often this rhetoric pays limited attention to the heterogeneous nature of categories like "women" and conflicting interests that arise within them over access to and control over resources[24b][14a]. JFM policy seems to assume that all users are equally capable of participating in community management institutions, irrespective of their socio-economic and political status, and their institutional environment[2b].
The power of these disparate actors to have their voices heard and interests recognized in turn affects the use and management of forests and their contained resources. However, few studies on JFM have looked at "who, within communities and households, has gained and who has lost by class, caste, ethnicity and gender"[15d]. Given that Joint Forest Management has been conceived within a bureaucratic structure to be universally implemented across India, its top-down conception of management does not leave much room for distinct voices[13f]. For example, a research study on village forest committees (VFCs) in Karnataka found that the majority of non-members were from the poorest households in the village[13g]. Ultimately, the opportunity costs of protection, closures and appropriation or sale of community forest resources are more greatly borne by the poor, landless or otherwise marginalized whose livelihoods depend predominately on these resources, but who are not able to participate in decision-making[26].

\section{BARRIERS TO WOMEN'S EFFECTIVE PARTICIPATION IN JFM}

Numerous studies have indicated that a key issue in JFM and other participatory approaches to community forest management in India is a lack of women's participation. An often cited reason for this exclusion is that women feel socially inhibited, especially when asked to express their opinions in front of male community and household members[8c]. Such "shyness" and gendered norms of behaviour are conceived of as cultural barriers to women's participation at meetings. In a study on community forestry participation in Orissa, Ostwald and Baral (2000) found that men and particularly upper caste men were much more vocal than women in terms of their opinions, attitudes and roles surrounding JFM[14d]. Women's perceived roles are traditionally centred around the domestic sphere within the gendered division of labour in rural areas. Gendered social norms have traditionally excluded women from participation in public decision-making forums[5b]. This can apply particularly to higher caste women, for whom their status limits their involvement in certain public spaces[14a][7b].

Male attitudes towards women's involvement in village forest institutions can be reflective of these wider social norms. A male leader of a village Forest Protection Committee (FPC) in Orissa stated: "We are not so modern that we should involve women in the FPC"[27a]. Other members expressed similar reservations in involving women, as they are "the main destroyers of the forest"[27a]. These statements reveal staunch opposition to any initiatives that would seek to include women in resource governance. Women are also excluded from participation in community forest institutions because of their heavy work burdens in and outside the home[20f]. This is especially true for very poor and otherwise marginalized women, along with other user groups as well, such as men from Scheduled Castes (SCs) or 
Scheduled Tribes (STs) who depend heavily upon forest resources.

Apart from traditional social norms that exclude women from effective participation in community resource management, there exist a number of policy barriers to women's inclusion. The National Forest Policy of 1988 clearly mentions that women should be involved in achieving JFM policy goals. The Ministry of Environment and Forests (MoEF) stated that one of the main objectives of JFM was in "creating a massive people's movement with the involvement of women"[20c]. However, the circular produced by the MoEF in 1990 gave no mention of women and only refers to 'beneficiaries'[20d][19a]. This uncertainty surrounding the role of women in JFM policy is made apparent in local institutions. In an attitudinal assessment conducted in 14 village forest committees in Madhya Pradesh State, forest personnel agreed that women should significantly contribute towards JFM, but they could not say how women should be involved[8d]. These ambiguities in JFM policy combined with gendered social norms that excuse women's lack of participation perpetuate exclusions. In many cases, it appears that 'local culture' is used as a scapegoat to explain women's omission from community management institutions.

Within official national policy, women are considered a marginalized homogenous group requiring attention. Generally speaking, the program has focused on gender in terms of formal provisions for women on executive committees and governing bodies at the village level[28a]. Women's usefulness has also been recognized in terms of their "special values, knowledge and use of forest resources"[20d][19a]. It is assumed that women have a special relationship with the environment and that this will translate into women's conservation of forest resources. No clear guidelines exist in terms of how women's close relationship with forests as a source of livelihood should be applied to forest management policies and programs. As Catherine Locke (1999) discusses, there is no clear gender planning under JFM. Gender within JFM policy acts as a "technocratic measure, resulting in its depoliticization" as gender planning accounts for women's physical presence in community forest institutions rather than their means of struggle for substantive participation[25]. A case study from Uttar Kannada, Karnataka reveals that women who were members of the managing committee did not know anything about the forest policy or their role within the village forest committee[28b]. Thus, lack of directives within JFM policy and in its implementation mechanisms remain a barrier to women's participation.

There is a marked difference between formal and substantive equality. Merely stipulating that female members be registered within local forest management institutions does not translate into their active involvement and participation in decision-making processes and outcomes. Often VFC reservations for women go towards the spouses or relatives of male members, who are typically higher-caste women and who may not understand the forest needs of poor and landless women[13h]. It is also common for women VFC members to not be informed about meeting times, or for these to take place at night or other very inconvenient times when women have household chores to perform. In these ways, women's participation in community forest institutions can serve a merely 'cosmetic' purpose[27b]. In some states, policies for representation still exist which require one adult representative per household for membership on the General Body of the community forest management institution. This policy generally translates into one man from each household[20d]. According to Sarin (1995) in her gender analysis of JFM, the policy is "effectively equating people's participation with men's participation because of its assumption that as 'heads of the households' men adequately represent the interests of all household members"[5c]. These requirements exclude female membership and result in limiting women's ability to exert control over what is entrenched as a male entitlement[13h]. Other stipulations for one male and one female household member on local committees are more inclusive, though these positions will generally go to older female household members with greater seniority and more indirect involvement in forest resource collection and use.

The processes of microplanning used to collaboratively determine forest management options also present barriers to women's effective inclusion in JFM programs. The microplanning structure uses participatory rural appraisal (PRA) tools outlined in the National JFM Support Group's Fields Methods Manual. This Manual asserts that microplanning can assess the environmental values, knowledge and roles of women in a community. In gathering this information, environments are conceived of "essentially as physical worlds, that is spaces 'uncontaminated' by cultural and social meanings"[18e]. Particular resources and their uses by various groups are assessed and it is assumed that this gender-specific information will inform dialogues in which forest management decisions are made. By leaving decision making processes up to open "dialogue" the manual overlooks the fact that these decisions "will frequently depend... on the political or bargaining power of the various stakeholders involved"[18g]. Merely assessing the uses of village forest resources by different groups does not mean that the interests of these groups will be equally recognized. Marginalized groups, including poor men, are overlooked in this process and decisions enacted by the local forest institutions generally reflect the views of village elites[18h]. The diversity of group interests are effectively left out of the process, as are aspects of power, access and control which frame resource use. The ways in which different groups of women are using forest resources and to what purposes is generally not considered. Whether women are collecting forest products for sale to accrue savings or for direct household consumption is not assessed, along with their motivations such as lack of employment or land holdings. 
This information is not deemed as relevant to microplanning and the impact of JFM on women[18i].

Without measures in place to include the participation of women and marginalized and landless groups in local resource decision-making, it is unlikely that these groups will benefit from JFM[18j]. It is problematic to assume that women's formal representation within local forest management institutions will translate to an ability to voice their interests and opinions on these male-dominated committees. These policy limitations and social barriers faced by women combine to effectively exclude their participation in decision-making. Little state commitment has been made to reverse these mutually reinforcing social, political and policy-based factors which perpetuate women's exclusion. A gendered political ecology approach towards policy analysis and implementation needs to be taken in order to understand structures that exclude marginalized groups and means through which their participation can be enhanced.

\section{UNDERSTANDING WOMEN'S EXCLUSION WITHIN JFM PROGRAMS}

Forest department staff generally continue to regard timber as the most important product to be derived from the forest, and to categorize other forest products as of minimal importance. Preference for forest species is highly gendered. Timber continues to be a male domain within contemporary forestry initiatives, excluding women's participation in local and national institutions that manage these resources[14a]. Men, and more specifically higher caste and wealthier men, are privileged in terms of knowledge of forest management. They have more experience in managing woodlots and market-oriented agroforestry systems than women who have traditionally collected resources from community or state forests. These relationships are easily translated into JFM practices in local institutions in which these elite men take on an authoritative role in managing forests. Thus, "[i]n practice those who are 'privileged' with knowledge are likely to be those who are also privileged with access and control over forest or tree resources over the longer term"[18m]. Numerous studies have indicated that while men have a strong preference for timber species used towards commercial and personal purposes, women prefer those species that meet their household subsistence needs[7d][14e]. NTFPs are often of high importance to forest-dependent women given their accessibility, time required for collection, and use for direct consumption or sale; NTFPs do not entail years of economic uncertainty as with timber. These minor forest products provide important subsistence and economic benefits to households, and for this reason, the opportunity for NTFP benefits to accrue through a community forestry initiative will be important in determining community members' willingness to become involved with and to sustain forest protection initiatives[7a].
In numerous cases, male management values and practices towards commercial enterprise are institutionalized at the village level under JFM. For example, fuel wood from these plantations may be cleared and sold in large lots, effectively excluding poor households from legally acquiring such timber[27a]. Within one Karnataka VFC, only six of the 97 members were women[13i]. Women's marginal presence within such VFCs further limits their bargaining power in the context of patriarchal norms. When the VFC decided to sell off the firewood from their 30 hectare village plantation, there was little effective opposition from women who could no longer collect fuelwood and fodder from the plantation[13i]. The increase in work burdens for such marginalized groups does not predominately affect men who typically 'make the rules' because collecting fuel is typically women's work[13i]. This presents a challenge to user participation as the interests of elite community members are more powerful than those of landless groups with less political and financial influence. Similarly, in a 1995 case study from Gujarat, several men in the community re-opened a closed area of protected forest to generate a sustainable timber plantation, while women's desire for a designated area of forest for collecting firewood closer to the village was neglected[18n].

While poor women have extensive knowledge of minor forest products, this knowledge is undervalued. JFM policy and practice effectively privileges elite voices and interests in assuming that community resource management is not a political process, occurring within gendered and otherwise stratified power structures. Under the gendered nature of forest collection in India, male interests are institutionalized and privileged. While male firewood collection on private property generates income, female collection is unpaid, generally on public lands, restricted, stigmatized or otherwise controlled. Thus, the relationships between livelihood tasks and tenure are highly gendered. They speak to the values that are maintained surrounding resource use and gendered livelihood relationships to the environment. While men's work and access to resources is formalized and entitled, women's work is far more precarious[18k]. Attempts to increase women's participation while failing to acknowledge such gender inequalities "will constitute little more than a further increase in the unpaid contribution of women to development programmes from which they receive little benefit"[181]. Disconnecting resource use from social relationships and gender can potentially reify gender inequalities through their reflection in forest policy and management practices.

Though JFM policy has a stated intention to improve women's livelihood situations, in some ways JFM practices systematically undermine them. Forest use rules are often enacted without participation or consultation of affected user groups[7c]. These groups are differently affected by such rules on the basis of their class and gender, and strict rules most adversely affect landless and poor households and women[29a]. Closure of forest areas for regeneration and 
sale of timber from village plantations are often carried out without consulting women users and without consideration for how women will obtain forest resources for their household. Village control over forests can result in the taxing of resources or the closing off of forests for daily collection. Village plantations under JFM may also be established on village commons which landless groups had traditionally used to graze animals, collect fuel, fodder, and plants for subsistence purposes[13i][4b]. Marginalized women may want plantations closer to the village from which they can gather resources, but these factors do not generally influence decisions reached in VFCs[14d].

The effects of forest degradation and restrictions on forest use are disproportionately borne by poor women in India. Women's income from the sale of predominately NTFPs is negatively affected when forests are degraded or when reforestation programs neglect these 'minor' forest products in favour of timber plantations. Household, and predominately women's health and nutrition, are negatively affected as well when fuel and foods gathered from forests are no longer accessible. Women's social networks and knowledge systems are impacted when they are not able to engage in livelihood securing activities that depend upon access to and availability of forest products[19b]. As a result of disregard for the needs of forest-dependent women, they must travel and work for longer periods of time in order to obtain resources with the risk of being fined or beaten if they encroach upon protected territories. In these ways, JFM often serves to remove authority from the hands of forest department officials and empower elite men within communities to carry out the role of resource control and policing. This investment of power in many ways has exacerbated gender inequalities at the community and household levels.

It has been recognized that traditionally disadvantaged groups are incurring losses under these policies and that they need to be more involved in community institutions, but little has been done in practice[18p]. The marginalization of forest dependent groups under JFM results in the alienation of certain groups from securing their livelihoods and participating in sustainable resource management processes. It is through "the[se] more invisible and subtle processes of exclusion, delegitimization of their traditional resource use patterns, use of monetary and wage incentives from plantations [rather than] making existing forest dependent livelihoods more sustainable, that... the current implementations of JFM are subtly, but systematically further disempowering the already marginalized and resource poor'[13d]. These effects of community conservation under JFM are not being considered and there are no substantial measures that have been put in place by the state to mitigate them. Exclusion and further marginalization of women and resource poor groups is evidence that the state participatory rhetoric within JFM policy has not translated into action.

\section{ROLE OF WOMEN IN JFM: POLICY AND PRACTICE}

Catherine Locke (1999) argues that JFM policy in India takes a "women, environment and development" (WED) approach in assuming that the involvement of women will aid in overcoming environmental problems, such as forest degradation. Women's involvement is often viewed in terms of increasing project efficiency because their productive roles are so involved with forest resources[18q][25c]. Thus in theory, the inclusion of women is advocated, not on the basis of addressing women's livelihood needs, but in attaining conservation goals[28c]. For this reason, practically all documents on environmental projects at least allude to the role of women in securing project outcomes[20d]. The WED approach ingrained within JFM policy assumes that women's interests can be inferred from their current forest resource uses and activities without grasping the social, economic and political conditions that mediate this relationship women have to community forests. Women's disempowerment also remains a barrier in their ability to address individual and collective interests through forest institutions[18s].

Different groups depend more prevalently on nontimber forest products in India, and among these groups, women and particularly tribal women, are the most dependent[26a]. "As the 'main victims' of environmental degradation, women are seen as being the 'most appropriate participants' in environmental conservation"[18r]. This understanding of women as more inclined towards environmental conservation based on their roles in forest resource collection can run the risk of naturalizing gendered inequalities that denote what is and is not women's work. A "gender and development" (GAD) approach instead views gendered relations to environmental resources as a reflection of social relations, entitlements and capabilities created and maintained through structures of power and authority[28d]. While women may be engaging in various types of forest work in order to secure their livelihoods, cementing them within categories such as leaf-collectors "may cause JFM to engrain low status, low return work as 'women's work"'[18s] and determine women's ability to carry out this work as a reflection of their political status. Forest department assessments of women's current practical needs, rather than their strategic interests, may in fact relegate them to a very low position within the gendered division of labour.

GAD does not conceive of women as an undifferentiated category but as agents who are able to contest gender relations and the ways in which their power and control have been weakened through traditional community management practices[18t]. Locke (1999) writes that "adopting a GAD approach will involve challenging policy frameworks that are grounded within WED, redefining the kinds of understandings needed for gendersensitive planning, and establishing how to monitor changing gender relations in the context of JFM"[18u]. A gendersensitive policy approach through JFM should attempt to find "ways in which women can institutionalize the few 
bargaining strengths they have, and in working out leverages and incentives that would ensure a voice and space for the most marginalized groups within decision-making processes"[18v].

A user group's knowledge of the environment does not necessarily translate into strategies for environmental biodiversity, but it can be utilized towards regeneration activities. The opportunities for resource knowledge to be used towards conservation of forest species is likely to increase if forest-dependent groups are the beneficiaries of these initiatives through, for example, improved access and rights to forest resources. Across various communities surveyed in Himachal Pradesh, Agrawal and Chhatre (2006) found a positive correlation between how villagers felt they were affected by forest loss via subsistence activities and an expressed need to conserve and protect forests. Those who perceived themselves to be the most affected through forest degradation expressed the most desire to protect these resources[20e]. They also observed that the involvement of women in institutionalized decision-making created better conditions for forest resource conservation[20e]. As women are the primary collectors of forest products in India, particularly in hill areas, their role in the institutionalization of local rules on forest products could meet their needs and aims for preserving a valued resource base[20g].

Due to the barriers limiting women's participation in community forest institutions, it has been identified that allwomen groups and women field staff can potentially overcome these obstacles[18f]. However, these groups remain exceptions in community forest management in India, and are generally located in tribal or hill areas[18h]. In a study of all-women's community forest institutions in Gujarat and Nepal, Agarwal (2009b) found that these groups tend to be given smaller and more degraded plots of forest. Irrespective of this, indicators showed that in VFCs that had more women on the executive councils, forests were in better overall condition and showed improvement over the period of survey[30a]. General findings indicated that the more women were on the executive committee (EC) in Gujarat, the lower the percentage of degraded forest area in the community[30b]. Furthermore, forest dependent women's control over forest decisions enhances their livelihoods as it allows them to plan around collection activities[31a]. Thus, it appears that women in India can play an important role in community forest management. Over time, women's contribution to conservation efforts and collective presence within local institutions can also challenge gendered social norms that exclude them from decision-making processes[7e].

Agrawal (2009a) found a positive correlation between women's involvement in rule-making and forest regeneration. Importantly, the process through which rules are made impacts how they will be observed. If user groups are involved in the process of rule formation they are more likely to accept them, even if they are restrictive[29a]. As women are the predominant gatherers of forest products under the gendered division of labour in rural India, they would benefit from creating rules that are capable of implementation. The imposition of overly restrictive rules on forest product collection is not beneficial to either sustainable environmental management or meeting local needs as they will inevitably lead to rule-breaking by dependent groups[7d]. Similarly, Sekhar (2001) states that "the prospects for securing local cooperation and rule conformation for managing and preserving the resource improve if there is wider representation of the community in the organization"[26b]. According to a study in 2006 concerning water user groups in India, research also indicated that participation in rule formulation was positively related to rule compliance[29a].

The institutions governing local resource management are more likely to be sustained through the participation of main stakeholders. Women however, have been largely excluded under JFM as representatives on both village executive committees and general bodies and thus from processes of rule formation. Women have also been excluded from the sharing of benefits because they have little say in what these benefits will be and how they will be distributed[7f]. Generally, the case is that "men make the rules for forest use, while women make do"[180]. Aside from making the rules men are also generally in charge of implementing them; the predominant members of patrol groups responsible for guarding protected forest areas are men. However, as men are the not the primary stakeholders over forest products and women do the majority of fuelwood, fodder and food collecting from forests, male guards or patrol groups fail to recognize resource depletion. Women are much more familiar with the forest and its products than men, and informal women's patrols in Gujarat were able to identify illegal cuttings the male authorities had missed[7d]. In other ways, male groups often make decisions that compromise women's access to forest resources, such as removing roots and shoots important for women's collection to make room for commercially valuable plants[7a]. Women should be more involved in the process of community resource management to ensure that conservation goals encompass present and future stakeholder needs.

However, a gendered study of involvement in forest management in Orissa revealed that women's main form of participation in VFCs was in 'receiving information'; 68 per cent of women surveyed reported that this was through their husbands or other male relatives[14e]. Additionally, 83 per cent of women stated that they were not personally involved in forest management activities, such as guarding[14e]. Those who did state their involvement typically had more education[14e]. Education is invariably an important determining factor in participation within community institutions and barriers to women's inclusion in education and training need to be overcome to achieve more substantive participation. However, education initiatives alone will not be able to achieve such participation. 
By disregarding these social, political and economic structures and relations that limit women's involvement in public forums like VFCs, current practices under JFM are undermining possibilities for creating more participatory and sustainable resource management strategies. Gender approaches to policy making must go beyond the stipulation that women be involved in community forest management, to address how gendered power structures that exclude women's participation can be overcome and changed with time. Women's involvement in this regard would entail "ensuring that those affected by the rules participate in framing and modifying the rules" and in creating more appropriate mechanisms for meeting household needs, dealing with offenders and handling conflicts[7d]. However, there is a lack of gendered analysis of decision-making processes in VFCs recognizing the ways in which household and community resources are managed and the impacts these are having on marginalized groups[18n].

In order for women to benefit from forest management initiatives, they must be much more involved in decisionmaking concerning management processes. At present, women in India remain excluded from meaningful participation in community forest management, and this exclusion continues to have negative effects on women's socio-economic and political status. If the needs of marginalized forest users cannot be fulfilled through local forest management institutions, this will likely increase the work burden of poor women, lead to rule-breaking, and perpetuate situations of livelihood insecurity. The maintenance of such inequities are not conducive to participatory and sustainable resource management. If women continue to be excluded from participation in community resource management initiatives and men continue to dominate these political circles, women's rights and needs will effectively continue to be subordinated within gendered political hierarchies that privilege male, and particularly elite male, voices.

\section{JFM POLICY RECOMMENDATIONS}

The failure of JFM to be truly participatory is a reflection of structural barriers at the local and national levels. Without effective measures in place to ensure the participation of marginalized forest-dependent groups, decentralization of resource management to the village level has resulted in elite capture, serving the interests of village elites rather than those of the poor. 'Participation' through devolution of control and benefits to the community level has been largely viewed by the state as a means to enhance efficiencies through the reduction of transaction costs[13j]. The forest community is conceived of as a homogenous group with equally vested interests and power, informing participatory rhetoric on women's inclusion in village institutions that does not translate to their substantive participation in decision-making processes[15e]. Rural communities across India are extremely diverse as are the structures which have formulated them and the humanenvironment relationships contained within these seemingly homogenous groups. In some communities, such as higher caste Hindu groups, gender inequalities may be more pronounced than in tribal villages. A forest management policy needs to be grounded in a contextual understanding of these relationships if conservation efforts are to benefit the livelihoods of forest-dependent groups.

Participatory processes must recognize power structures at various levels that typically exclude marginalized groups and privilege some voices over others. The transformation of power structures is essential to this process. "A participation that fails to engage with the distribution and operations of power within local communities and the wider society in which they live is likely to offer little to marginalized groups"[13k]. The mere identification of stakeholders and creation of local democratic institutions does not ensure the participation of all groups. Non-participating groups will not benefit equally because their interests will not be equally represented[1c]. Beyond such facilitating measures, "participation requires wider processes of social transformation and structural change to the system of social relations through which inequalities are reproduced"[13k]. Presently, JFM policy fails to recognize that the participation of marginalized groups is a political process that requires structural change and capacity-building measures. Gender conceptions within JFM policy need to shift from those of a WED approach to GAD within a political ecology context in order to understand such exclusions and the structures that enforce them[28a].

It should also be recognized in forest policy that promoting forest conservation requires meeting the needs and interests of groups who are dependent upon forest resources. Issues of poverty, inequity, and resource sustainability are highly connected. Addressing these concerns demands that the needs and interests of marginalized groups are also given priority. Women's lack of participation is both an effect and a cause of poverty; the impoverished have limited power to voice their interests and this inability to participate in forest use decision-making has negative effects on women's livelihood opportunities. Any policy which decreases livelihood opportunities for forestdependent group will exacerbate these issues, including forest resource sustainability.

Policies and rights must evolve to serve changing needs, and remain flexible and responsive to the needs of vulnerable groups. While JFM policy seems to have modified who is managing forests by shifting control to the village level, how forests are viewed and managed has not greatly evolved since the days of colonial forest management. Forests are still considered the property of the state and despite participatory rhetoric, management policy is not reflective of the needs and interests of all forestdependent groups[27c]. Rather, JFM policy often serves to entrench the interests of elite groups within local management institutions. Simply placing control over 
resource management within the hands of the community empowers those who are most capable of exercising their voices with authority[13k].

India's forest policy should contain clear gender guidelines that create spaces for women and marginalized groups to participate in decision-making forums beyond the mere acts of attending meetings and voting. A gender-neutral policy design cannot elicit women's effective participation[1d]. Rather, their participation in monitoring and evaluation of project activities should be detailed in forest policy and appropriate benefit-sharing mechanisms more clearly outlined in communication between community user groups and state forest departments. Forest Departments dictating the use of PR techniques to forest communities is not sufficient[131]. Rural capacity-development and extension within the forest department can play a role in monitoring policy implementation within communities, such as documenting levels of women's participation in local decision-making institutions. A major issue is also the exclusion of women within forest department bureaucratic structures, which reflects female exclusion from village institutions.

Forest policy needs to balance conservation goals with livelihood needs and secure the sustainability of both through the extension of secured rights and benefits and participation in environmental management activities. Rights should be articulated from below through processes that do not further marginalize minority voices and should be implemented in state bureaucratic practice. Rights within the current JFM framework are insecure and insufficient. These rights are not legally binding, contain ambiguous guidelines, and favour the state[27][16a]. Without rights to livelihood-securing resources and some degree of collective ownership rights over their collection, forest-dependent people have little incentive to conserve resources. The legal situation has changed since the 2006 Forest Dweller's Act, but in practice, rights to collect and sell NTFP are not being recognized across several states in India.

State policy alone is not capable of changing entrenched power structures that exclude women's participation in community decision-making[1b]. Intervention at the grassroots level is required for effective participation in any state-led program. Enhancing women's participation in local resource management institutions requires a holistic approach to promoting women's empowerment and livelihood rights and opportunities.

If alternative livelihoods are fostered within communities, they must also be reflective of women's perceived needs and incorporate methods to ensure their participation. The coordination of multiple capacity-building and livelihood enhancing programs may improve women's ability to participate in community conservation. Women's self-help groups (SHGs) have been formed within many villages for the purposes of developing savings, micro-credit and small business enterprises to enhance women's livelihood opportunities[32a]. Alternative livelihood opportunities that seek women's inclusion and utilize women's environmental knowledge ought to be implemented within JFM. One policy measure is to promote women-led village forest plantations or nurseries for a variety of timber and NTFPs with legal control and rights to these plantations. Other policy initiatives may include self-employment schemes such as women's agro-forestry plots, NTFP marketing cooperatives, rehabilitation efforts on wastelands and community commons, and integrated watershed development programs. Women's collectives can also be expanded upon and coordinate with capacity-building activities through literacy-focused and advocacy groups.

Enhancing women's participation also requires the sensitization of men. A gender approach to forest policy structures cannot only focus on women[32b]. Male attitudes predominately reflect social perceptions that women's involvement in community resource management is ineffective and that their knowledge is limited[7g]. The Government of India passed guidelines in 2000 asking states to ensure that 50 per cent of JFM general body members are women. This remains to be fully implemented, but even full implementation will not ensure substantive participation of women as long as social and gender inequities persist[7h].

\section{WOMEN'S EMPOWERMENT: CHALLENGES AND OPPORTUNITIES}

This examination of women's exclusion from community resource management institutions under JFM leads to questions of how these barriers can be overcome. Forest-dependent groups, including women, have been systematically disempowered through successive colonial and state forest policies, including Joint Forest Management. Reserving spaces for women in local institutions is insufficient, as formal representation does not render women's inclusion[25d]. Oppressive power relations need to be challenged along with the social, political and economic structures that perpetuate them[13m]. Without measures to ensure women's real involvement, such 'participatory' approaches will continue to privilege the voices of elite males within communities and reinforce the status quo[25e].

Batliwala (2007) discusses how empowerment as a concept for change in India has become co-opted and depoliticized within government bureaucracies and development planning. Gender sensitization, training and capacity building often employ neo-liberal frameworks that narrowly interpret women's multiple identities and needs[33]. Such overly simplistic notions of women's empowerment do not conceive of equality as a measure requiring substantive political change. "As 'empowerment' has become a buzzword in development, an essential objective of projects, its radical, challenging and transformatory edge has been lost. The concept of action has become individualized, empowerment depoliticized"[25f]. These development discourses about gender inequality shape the types of spaces in which rural women can assert 
themselves and challenge gender norms[25e]. Thus, the mainstreaming or cooptation of empowerment may pose limitations to its use in opening participatory spaces for women within state-led community resource management initiatives.

True empowerment is a process that ultimately aims to alter power relations, restore individual and collective autonomy, enhance participation and build awareness through capacity-building and the strengthening of personal agency[34a]. In this process, people are social actors, agents of change and not merely passive recipients of state-led programs[24a]. Empowerment is a tool for collective change and not an externally imposed policy instrument. Poor women's empowerment is also likely to require the disempowerment of certain groups[131]. However, forest policy in India seems to conceive of empowerment for poor and marginalized groups as something that can be delivered through community forest institutions without any consideration to existing power structures.

The empowerment of women's groups in rural India is required for their effective participation in resource management under JFM. There is a need for women in India to overcome barriers limiting their participation which have been institutionalized through the state, the community and the family[7a][19c]. Empowerment in this regard can entail women's redefining of social limits, including norms and value structures, that determine group participation[34b]. It is about confronting and transforming structures and ideologies like patriarchy through new ideas, information and self or collective awareness[35]. In particular, capacity-building generally accompanies empowerment processes, through means such as enhancing education, leadership and literacy skills. Sustained capacity-building measures can raise women's self-confidence so that they have a collective presence and are able to exercise their voices in public forums[7i].

Women have to consciously construct their own spaces for social change. There are some existing state mechanisms through which women's empowerment is being targeted, such as Mahila Samkhya programs which focus on mobilizing women[31b]. Similarly, women's organizations such as mahila samitis can provide women with a separate community space that enhances women's social visibility, and can become a collective space for solidarity and collaboration with other local institutions for change[25d]. As formal and stable institutions, these women's groups can potentially be incorporated within village structures over time and coordinate with other groups. Such formal legitimacy can offer these groups bargaining power at the household, village and state levels[25d]. These groups also gain legitimacy as they are seen to contribute financially to their households and community through savings, loans and other collective micro-enterprises[7i]. In creating their own spaces for social action and for gaining visibility, women also make men visible as they no longer remain a neutral category, and gendered structures of community exclusion may be exposed and challenged through the exercise of women's collective agency[25g].

There are a few extraordinary examples of all-women VFCs and mahila samitas managing forests in some villages. Sarin (2001) provides an example of women's development of community forest management (CFM) institutions in Uttarakhand. The presence of these institutions has been linked to the exposure and self-confidence women gained through Mahila Samakhya programs that created management roles within women's collectives, such as patrolling forest areas. While these groups faced a lot of initial opposition from powerful groups and male relatives, their persistence has led to extensive regeneration of women's forests[31c]. Women, through the exercise of their own agency, have carved out informal spaces and roles for themselves in protecting forest plantations, and are gaining recognition from their successful outcomes[27d]. Where these women's institutions are present, they need to be strengthened to prevent their subordination within externallyfunded and implemented conservation programs, including JFM[31d]. These state-led policy programs do not conceive of women's empowerment as a necessary process within community resource management. In contexts where spaces for women's empowerment are absent, NGOs, international donors and forest officials have a catalyst role to play in their initiation[7j]. These non-community actors can also play a facilitative role in soliciting women's opinions and representing their expressed needs within community and state institutions; an initial step which may be necessary in the empowerment of extremely marginalized groups. For example, NGOs have played key roles in advocating for rights and attracting publicity to increase the bargaining power of smaller groups against the state. In numerous cases, this has led to user groups demanding recognition of their rights and benefits under state policies[13a].

\section{LIVELIHOOD RIGHTS AND FOREST POLICY}

Through the history of state forest legislation in India, traditional forest resource rights have been eroded. For example, historic tenure rights of SCs and other forestdependent groups like shifting cultivators have not been upheld through JFM. Under current policy, these groups are often categorized as encroachers upon JFM plantations[4c]. While the land and resource rights of tribal groups are supposed to be protected under the 2006 Scheduled Tribes and Other Traditional Forest Dwellers Act, in practice these rights are not equally upheld[36]. In Andhra Pradesh for example, 60 per cent of the State's Schedule V area set aside for these groups has been declared as reserve forests and effectively closed to users, despite legal protection under the Forest Dweller's Act[4d]. Under JFM, as well as other forest policies, forest lands continue to be appropriated by the state and their legal status altered without concern for the impacts on local livelihoods. 
Through the current JFM policy, usufruct rights and benefits are often highly constrained to a small percentage of forest management institution members, and women generally receive few of these[28e]. This is because forest rights often entail viewing forest resources as property. This can result in the leasing out or sale of forest resources, which, as discussed, can alienate those dependent on these resources. It is problematic that on a wider scale, JFM policy focuses on improving livelihoods through commercial timber-based activities[16c], which case studies have revealed typically exclude women and marginalized groups. As it is generally the landed elite who make and enforce forest use rules within local institutions, their own rights and privileges tend to be secured without concern for effects on other groups[24b].

A prime example is the case of women's rights to minor forest products, the sale of which is a main livelihood source for women in forested states such as Orissa. Currently however, the export, import or removal of NTFP from a community is illegal in some state forests without authorization from a forest department official[16d]. Rights and access to these NTFPs need to be enhanced and institutions such as women's cooperatives ought to be formed to market these products for the benefit of collector groups. Within state forest departments and VFCs, greater acknowledgement of community and specifically women's tenure rights to forest resources can provide a solid foundation on which women can publicly demand recognition for their rights in actual practice[25h].

Safeguards must be put in place to prevent leasing out of forest resources or alterations in land use that degrade livelihood opportunities[27e]. Rights ought to be implementable in a manner that challenges power structures and the cooptation of community forest rights to benefit a select few[27e]. If JFM is to improve, there needs to be greater coordination between state forest departments and communities to integrate legal rights within JFM frameworks and to uphold these where gaps are perceived[16b]. Both tenure rights holders and FD staff need to be informed as to what these rights and responsibilities entail within forest policy. An independent review of JFM in Karnataka recommended that community obligations under JFM policy be balanced by more clearly defined rights[13i]. These should include rights to maintain village commons and support for a variety of livelihood strategies that can be undertaken in coordination with forest conservation efforts. Denying collection rights to resource poor groups will not result in any sustainable alteration of livelihoods. Such alienation from community resources will likely exacerbate situations of poverty that are seen as a cause for resource degradation in the first place. In the absence of secure tenure rights over forest resources, user groups do not have many incentives to engage in long-term management of these resources. As long as forest policy continues to marginalize and criminalize forest dependent groups, neither their livelihoods nor the gains from state-led conservation efforts will be made sustainable.

\section{CONCLUSION}

It is not effective to invest more resource control in local communities without measures for the empowerment of marginalized groups to access these decision-making forums, and without more effective rights in place to ensure their benefits from participation. Through JFM there needs to be better state-led implementation of legal rights contained in the PESA Act and the more recent Forest Dwellers Act. This is likely to require more on-the-ground monitoring by the State Forest Department and coordination with NGOs who have an effective mandate for promoting human rights and gender equality.

Participation and local control should be conceived of as goals in and of themselves and not as a means to reduce bureaucratic financial burdens. Effective participation in resource management can empower marginalized groups and carry positive effects on equity, sustainability and efficiency[7k], as case study evidence has demonstrated. Women, and particularly the most socio-economically marginalized and forest-dependent women, need to be involved in these processes of decision-making if forest management is to be participatory in practice and not just in rhetoric.

Poor tribal women, as the most marginalized of stakeholders to forest products under state forest policies, need to be politically empowered in any participatory process. The success of JFM programs in reversing forest degradation and improving rural livelihoods will require the carving out of a greater role for forest-dependent groups, especially women. Both within and outside of state policy, measures to enhance women's participation must take into account social relations and structures that perpetuate women's exclusion. Such a holistic approach to enhancing women's participation in community resource management would necessarily require women's empowerment and genuine recognition of their livelihood rights and opportunities.

\section{REFERENCES}

1. Agrawal, Arun and Krishna Gupta. 2005. "Decentralization and Participation: The Governance of Common Pool Resources in Nepal's Terai" in World Development 33(7), a: 1101; b: 1110; c: 1102; d: 1111.

2. Behera, Bhagirath. 2009. "Explaining the performance of state-community joint forest management in India" in Ecological Economics 69, a: 177; b: 178; c: 180; d: 179.

3. Kaushal, K. K., V. K. Melkani and J. C. Kala. 2005. "Sustainable poverty alleviation through a forestry project in Tamilnadu State of India" in International Journal of Sustainable Development \& World Ecology 12, a: 347 . 
4. Sarin, Madhu. "Moving Beyond the Present JFM Framework: Need to Recognize the Plurality of Institutions and Community Rights for Making State Community Collaboration Sustainable" in Bhattacharya, P, A.K. Kandya and K.N. Krishna Kumar (ed.s) Joint Forest Management in India, vol. II. 2008. Aavishkar Publishers: Jaipur, a: 430; b: 432; c: 437; d: 438.

5. Sarin, Madhu. 1995. "Regenerating India's Forests: Reconciling Gender Equity with Joint Forest Management" in IDS Bulletin 26(1), a: 83-91; b: 84; c: 83.

6. Agrawal, Arun and Clark C. Gibson. 1999. "Enchantment and Disenchantment: The Role of Community in Natural Resource Conservation" in World Development 27(4), a: 629-49.

7. Agarwal, Bina. 2001. "Participatory Exclusions, Community Forestry, and Gender: An Analysis for South Asia and a Conceptual Framework" in World Development 29(10), a: 1623-48; b: 1640; c: 1628; d: 1637; e: 1645; f: 1635; g: 1639; h: 1643; i: 1644-5; j: 1629; k: 1624.

8. Rishi, Parul. 2007. "Joint Forest Management in India: an Attitudinal Analysis of Stakeholders" in Resources, Conservation and Recycling 51, a: 346; b: 347; c: 350; d: 351 .

9. Gorakshkar Mukund. "Right Based Advocacy Needs for Grassroots Involvement in JFM" in Bhattacharya, P, A.K. Kandya and K.N. Krishna Kumar (ed.s) Joint Forest Management in India, vol. I. 2008. Aavishkar Publishers: Jaipur, a: 95 Forest Policy of 1952, para. 13; b: 95 ; c: 96 .

10. Hobley, Mary. Participatory Forestry: The Process of Change in India and Nepal. 1996. Overseas Development Institute: London.

11. Rajasekharan Pillai, K. And B. Suchintha. 2006. "Women empowerment for biodiversity conservation through self help groups: a case from Periyar Tiger Reserve, Kerala, India" in International Journal of Agricultural Resources Governance and Ecology 5(4), a: 340.

12. Someshwar, ShivSharan. "People versus the State? Social Forestry in Kolar, India" in Friedmann, John and Haripriya Rangan, (ed.s) In Defense of Livelihood: Comparative Studies on Environmental Action. 1993. Kumarian Press: West Hartford, Connecticut.

13. Hildyard, Nicholas, Pandurang Hegde, Paul Wolvekamp and Smasekhare Reddy. "Pluralism, Participation and Power: Joint Forest Management in India" in Cooke, Bill and Uma Kothari (ed.s) Participation: The New Tyranny? 2001. Zed Books: New York, a: 62; b: 61; c: 66; d: 66 Saxena et al. 1997; e: 63; f: 57; g: 64; h: 65; i: 67-8; j: 59; k: 68-9; l: 70; m: 56.

14. Ostwald, Madelene and Ranjan Baral. 2000. "Local Forest Protection, Gender and Caste - Dhani Hill, Orissa, India" in Geografiska Annaler 82 B, a: 117; b: 115; c: 116; d: 127; e: 121.
15. Conroy, Czech, Abha Mishra, Ajay Rai, Neera M. Singh and Man-Kwun Chan. "Conflicts Affecting Participatory Forest Management: Their Nature and Implications" in Vira, Bhaskar and Roger Jeffery (ed.s) Analytical Issues in Participatory Natural Resource Management. 2001. Palgrave Publishers: New York, a: 170; b: 184 Hill and Shields 1998; c: 168 Ostrom 1992 in Conroy et al. 2001; d: 168 Sarin 1998; e: 167.

16. World Bank. 2006. India: Unlocking Opportunities for Forest-Dependent People. Oxford University Press: New Delhi, a: 19; b: 59; c: 51; d: 21.

17. Balooni, Kulbhushan and Makoto Inoue. March 2009. "Joint Forest Management in India: The Management Change Process" in IIMB Management Review: 1-17.

18. Locke, Catherine. 1999. "Constructing a Gender Policy for Joint Forest Management in India" in Development and Change 30, a: 266; b: 265; c: $270 \mathrm{MoEF} 1988$ para 2.1; d: 270; e: 274 Mosse 1994; f: 274; g: 273-4 Grimber et al., 1994; h: 276; i: 279-80; j: 271; k: 279; l: 280 Mayoux 1995; m: 280; n: 277 Britt-Kapoor 1994; o: 277; p: 275-6; q: 268; r: 268 Shah and Shah 1975; s: 278; t: 268-9; u: 281; v: 282 Shah and Shah 1995.

19. Panda, Smita Mishra. July - Sept. 2000. "Gender Sensitive Forestry Interventions and Potential for Empowering Women: Illustration of a Framework" in Indian Journal of Agricultural Economics 55(3), a: 413, 415; b: 412; c: 420.

20. Agrawal, Arun and Ashwini Chhatre. 2006. "Explaining Success on the Commons: Community Forest Governance in the Indian Himalayas" in World Development 34(1), a: 158; b: 152; c: 152, 156, 163; d: 149; e: 159; f: 163; g: 161.

21. Peet, Richard and Michael Watts. "Liberation Ecology: Development, sustainability, and environment in an age of market triumphalism" ch. 1 in Liberation Ecologies: Environment, Development and Social Movements. Routledge: London. 1996.

22. Ostrom, E. 1990. Governing the Commons: the Evolutions of Institutions for Collective Action. Cambridge University Press, New York.

23. Gibson, C. 2001. "Forest resources: institutions for local governance in Guatemala" in Burger, E., E. Ostrom, R.B. Norgaad, D. Policansky, and B.D. Goldstein (ed.s) Protecting the Commons: A Framework for Natural Resource Management in the Americas. Island Press: Washington, D.C..

24. Geiser, Urs. "To 'Participate' with Whom, for What (and against Whom): Forest Fringe Management along the Western Ghats in Southern Kerala" in Vira, Bhaskar and Roger Jeffery (ed.s) Analytical Issues in Participatory Natural Resource Management. 2001. Palgrave Publishers: New York, a: 20; b: 19.

25. Arora-Jonsson, Seema. 2009. "Discordant Connections: Discourses on Gender and Grassroots Activism in Two Forest Communities in India and Sweden" in Signs: Journal of Women in Culture and Society 35(1), a: 215; 
b: 220; c: 231; d: 227; e: 236; f: 233 Frances Cleaver 2001; g: 235; h: 229 ..

26. Sekhar, Madhusree. "Organizations for Participatory Common Property Resource Management" in Vira, Bhaskar and Roger Jeffery (ed.s) Analytical Issues in Participatory Natural Resource Management. 2001. Palgrave Publishers: New York, a: 87; b: 78.

27. Singh, Neera M. 2001. "Women and Community Forests in Orissa: Rights and Management" in Indian Journal of Gender Studies 8(2), a: 259; b: 263; c: 269; d: 260; e: 268.

28. Sarkar, Debnarayan and Nimai Das. "Women's Participation in Forestry: Some Theoretical Issues" in Verma, R. B. S, H.S. Verma and Nadeem Hasnain (ed.s) Towards Empowering Indian Women: Mapping Specifics of Tasks in Crucial Sectors. 2007. Serial Publications: New Delhi, a: 378; b: 380; c: 376; d: 377; e: 384.

29. Agarwal, Bina. 2009a. "Rule making in community forestry institutions: The difference women make" in Ecological Economics 68, a: 2297.

30. Agarwal, Bina. 2009b. "Gender and forest conservation: The impact of women's participation in community forest governance" in Ecological Economics 68, a: 2793; b: 2794 .
31. Sarin, Madhu. 2001. "Empowerment and Disempowerment of Forest Women in Uttarakhand, India" in Gender, Technology and Development 5(3), a: 355; b: 342; c: 351-2; d: 359.

32. Thamizoli, P. and the MSSRF Team. 2001. "Integrating Gender Concerns into Natural Resource Management: The Case of the Pichavaram Mangroves, Tamil Nadu" in Indian Journal of Gender Studies 8(2), a: 205; b: 204.

33. Sharma, Kumud. "(Re)neogotiationg Power and Spaces: Reflections on Rural Women's Engagement with Politics of Development" in Kalpagam, U . and Jaya Arunachalam (ed.s) Rural Women and Development in India: Issues and Challenges. 2008. Rawat Publications: Jaipur: 277.

34. Mosedale, Sarah. 2005. “Assessing Women's Empowerment: Towards a Conceptual Framework" in Journal of International Development 17, a: 243-57; b: 251.

35. Batliwala, Srilatha. August 2007. "Taking the power out of empowerment - an experiential account" in Development in Practice 17(4-5): 560.

36. AITPN (Asian Indigenous and Tribal Peoples Network). 15 December 2006. "India's Forest Rights Act of 2006: Illusion or solution?" Online. Available: http://www.aitpn.org/Issues/II-09-06-Forest.pdf 